\title{
OVERVIEW OF ELEMENTS OF NATIONAL LOGISTICS SYSTEM IN THE REPUBLIC OF SERBIA
}

\author{
Petar Stanojević \\ University of Belgrade, Faculty of Security Studies \\ Vasilije Mišković \\ Educons University - Sremska Kamenica, \\ Project Management College, Belgrade \\ Zoran Jeftić \\ University of Belgrade, Faculty of Security Studies
}

\begin{abstract}
There are various interpretations of the concept of national logistics.
According to one of such interpretations, national logistics is a system which is comprised of resources, infrastructure and economy as its elements. This system functions in a general milieu set by the regulatory framework while interconnections of the system elements are established on the basis of mutual conditionality and interaction. Consideration of the elements of national logistics of a particular country renders the given term more concrete and specific features.

This paper addresses the elements of the national logistics system of the Republic of Serbia. Thus, a general overview of the system concerned is being presented since an elaborate description is not possible within the given framework. Such a general overview of the elements of the national logistics system provides the basis for assessment of different systems in the country, from economic to security systems.
\end{abstract}

Key Words: national logistics, system elements, resources, infrastructure, economy

\section{Introduction}

Ther here are various interpretations of the concept of national logistics. Some authors view national logistics exclusively as available resources, others as infrastructure, while third ones attempt to identify the national logistics with the economy as the basis for the entire corpus of state. There are also numerous additional combinations of understanding of this notion. However, that is beyond the scope of this paper. When speaking about national logistics, it is very difficult to speak about certain national logistics system. When considering the national logistics through the concept of a logistics system, it becomes immediately evident that this is an amorphous system. There are no solid links among the system elements and no solid structure established within the system. In this case, elements of the system function 
under identical spatial, regulatory, legal and other conditions. Interrelationships between the system elements are established on the basis of their functions within a general milieu set up by a state. At this level of discussion about the elements of the system, it has to be understood that the elements concerned are already highly complex systems themselves.

Many of these elements (in complex systems) are independent, most often, business entities. However, there are also elements that are centrally managed (also complex systems themselves), which most often include protection, security and defense systems. Consequently, to consider logistics and logistics systems in centralized systems (mostly business entities) on the one hand and national logistics on the other hand in the same manner would be very complicated. Therefore, it necessarily follows that national logistics itself needs to be defined differently both in terms of category and concept.

National logistics may be determined by its potential, which are resources and infrastructure, and by operational use of the resources and infrastructure, and that is the economy of a country. Resources, infrastructure and economy are the elements of this system. The system operates in a general milieu provided by the regulatory framework. The regulatory framework is determined by spatial, regulatory, legal and other conditions at the state level and various mechanisms at the international level to which the state concerned has committed itself. Connections between the elements are established according to their mutual conditionality, influence and relationships that are determined by the regulatory framework.

Resources imply everything that is provided by nature and everything that has been created as a result of interstate and international relations. This includes mineral reserves, agricultural land (in all its forms), energy sources, etc. Resources also include watercourses, location, climate, etc. The infrastructure comprises everything that people have created to enable the exploitation of existing resources, roads, railways, power plants, large irrigation systems, etc.

The economy of a country and its economic system imply operationalization of the use of these resources and infrastructure. Certainly, these two are not independent of each other. Resources are the factor which leads towards a greater or lower level of development of certain industries. Economic development directly influences the development of infrastructure, which, in turn, affects the conditions and level of resources utilization. National logistics can also be viewed in that sense.

The subject of this paper is the elements of the national logistics system of the Republic of Serbia in line with the interpretation of the national logistics given above. The intention is to provide an overview of various aspects of these elements. Certainly, this cannot be done without offering a glimpse of the regulatory framework and links between the system elements. The aim of the paper is to provide a general overview of the status of these elements. A more elaborate overview would require a lot more space.

\section{General indicators of Serbian economy}

The economy of Serbia generally follows the principles of a free market model. The largest sector is the sector of services /tertiary sector accounting for a total of $63.8 \%$ of GDP. Then the sectors of industry (19-23.5\% of GDP) and agriculture (12.7\% of GDP) follow.

According to estimations, Serbia's nominal GDP in 2015 amounted to USD 44.1 billion (according to the Ministry of Economy it is EUR 32.9 billion for the same year [1]). On the 
basis of the former amount Serbia is ranked somewhere between 80th and 90th place on the list of countries ranked according to GDP (sources of IMF, World Bank, CIA, etc.). The overall economy of Serbia accounts for $0.2 \%$ of the economy of Europe and $0.056 \%$ of the world economy, which makes it marginal when considered at a larger scale. Such economic potential substantially limits its potential political, military and security roles.

Major economic issues include the high unemployment rate and the foreign trade deficit. Also, there are high risks of so-called "education gap" due to abrupt lowering of investments into human resources, research and technological development as the basis for economic growth.

Regional imbalances are highly pronounced given that two-thirds of economic activities are concentrated in Belgrade and South Bačka District (Novi Sad) [1].

The average real growth rate in the last 15 years was 3.1\% [1]. In recent years, the investment rate was at the level of $16-18 \%$ of GDP. It is considered that in order to overcome the current technology gap, it would be necessary to achieve the share of investment of $25 \%$ of GDP [1].

The total level of foreign trade in goods is over USD 30 billion. We export about $43 \%$ of everything we produce and import about $54 \%$ of everything we use. Over the recent years, the import - export coverage ratio has been about $55-77 \%$, which places Serbia on the list of importdependent countries. Foreign trade in goods is the largest with the EU members and it is about $60 \%$. In regard to exports, our largest foreign trade partners are: Italy, B\&H and Montenegro. Our main export categories are automobiles, iron and steel, cables, metals, electrotechnics, car tyres, cigarettes, cereals, fruit and vegetables. Technology indicators for 2015 showed that almost $80 \%$ share belonged to low-technology and medium-low technology industries [1].

Agriculture, arms industry, computer science, wood and textile industries are the branches of industry that generate foreign trade surplus. Trade deficit is created by energy, chemical and metal industries. At the same time, the most dynamic sectors are: computer science, tobacco industry, manufacturing industry, textile manufacturing and manufacturing of machinery and equipment, as well as manufacturing of basic pharmaceutical products and pharmaceutical preparations.

The top import categories include oil, natural gas, vehicles, metals, electrical machinery and devices, telephones, machinery and equipment, steel and iron, which are primarily imported from Russia, Germany, Italy, China and Hungary. Our largest trade deficit is with China due to imports of cell phones and computers and with Russia due to imports of energy products - oil and gas.

A mere glimpse of the geographical map would be sufficient to realize that mainland Europe, Mediterranean Basin and Black Sea Basin are the areas of vital importance for Serbia since it has done its largest trade there so far.

\section{General characteristics of the current status of logistics and logistics organizations in Serbia}

In Serbia, logistics is still understood in a segmented manner and there is no agency or state authority that would oversee all related activities.

Due to its geographic location, networks of road and railway transport, airways and inland waterways, Serbia has the potential to become the logistics center of the region. However, it might be noted that, considering the current condition of railway and road networks, the area around Belgrade still represents the bottleneck for overall transportation of goods. 
At present, there are numerous logistics "providers" in Serbia, both national and foreign ones that offer the following services: transport, storage, processing of goods (product declaration and packing, sorting, repacking, etc.), implementation of reverse logistics, freight forwarding, customs brokerage, shipment monitoring, ensuring traceability, support to planning and creating a distribution and sales network, reporting on all aspects of movement and attributes of goods, as well as the services of building an entire logistics chain tailored to the specific needs of individual companies. These companies justify the need for using their services by the following benefits: improved forecasting, shorter delivery times, cost reduction based on loss and damage prevention, reducing response time and the number of complaints, and other benefits which help their customers achieve a competitive advantage.

The use of logistics management software such as routing, vehicle and cargo tracking has become commonplace in national logistics companies, as well as in the public administration for issuing various types of documents (for example, electronic declarations - 2 million customs documents for about 800,000 transportation vehicles that annually travel through Serbia).

"Logistics industry" is also responsible for its own environmental impact and it has to be transformed into the industry that efficiently decreases carbon dioxide emissions. Unfortunately, the implementation of the plan for decreasing the carbon dioxide emissions has not progressed far enough. Although many manufacturers and distributors continue to use their own delivery services, outsourcing logistics has become a global trend, i.e. companies transfer the responsibility for implementation of physical distribution to logistics „providers“. Many companies believe they make savings in this way.

\section{Characteristics of the regulatory framework}

As a part of the EU accession negotiations, our country has largely harmonized its national legislation with the EU directives by adopting numerous laws, strategies and by-laws. The outcomes will include provision of free access to Serbian infrastructure (power grid, gas pipelines, oil pipelines, roads, railways, ports, etc.) for all interested entities that meet the requirements related to trade in materials to be transported by such infrastructure. In addition to national public and other companies, a large number of foreign companies are about to enter the Serbian market in the area of transport and gas and electricity supply. This means that practically there will not be any national monopolies embodied by state-owned utilities.

Also, incentives will be introduced with the aim to improve the combined (intermodal), railway and river transport. The incentives concerned are intended for economic entities that will implement this type of transport. In turn, this will result in the development of this area, as well as in energy savings and reduction of emissions of harmful gases.

\section{Importance and characteristics of infrastructure in Serbia}

Serbia is located at the crossroads of the main transportation corridors, i.e. of the shortest road and railway interconnection between the Western-Central Europe and Southern Europe and the Middle East.

In 2015, 70.2 million passengers and 24.7 million tons of goods were transported. In Serbia, railway transport accounts for $52.8 \%$, road transport for $33.5 \%$ and river transport 
for $13.7 \%$. The explanation for the prevalence of railway transport can be found in the report of the World Economic Forum, where, according to the quality of the railway infrastructure, Serbia is ranked 83rd out of 144 countries, and even 111th in regard to road infrastructure and 127 th regarding river transport infrastructure. To some extent this is certainly influenced by the structure of the goods that are currently mostly transported in Serbia, that is ore, wheat, iron and petroleum products.

According to the same report, Serbia is in the 26th place in terms of the landline and in 57th place in terms of mobile telephony. Faster information flows have led to the use of more efficient business processes such as e-commerce, facilitating sales channels, optimizing distribution networks, introducing remote operation, online purchasing, online banking, more efficient logistics, e-government, and more.

In Serbia there is the following transport infrastructure:

AIRPORTS (Source: Civil Aviation Directorate of RS): 27 civilian (three international: Belgrade, Niš, Priština) and 7 military.

HELIPORTS 2015 (Source: Civil Aviation Directorate of RS): 2 (Dobanovci, Požega).

RAILWAYS (Source: PE Serbian Railways): 3,809 km (electrified 1,196 km) including $3,526 \mathrm{~km}$ of single-track and $283 \mathrm{~km}$ double-track lines.

ROAD NETWORK (Source: PE Roads of Serbia): total of $43,839 \mathrm{~km}$ including $15,018,510 \mathrm{~km}$ of state roads and $669,113 \mathrm{~km}$ of highways.

TUNNELS (Source: PE Roads of Serbia): 78 tunnels with the length of 10,053 m.

BRIDGES (Source: PE Roads of Serbia): 2,638 (7 across the Danube and 5 across the Sava River), 800,000 m long.

WATERWAYS (Source: Waterways Directorate of RS): 9 ports and 13 Harbourmaster's Offices.

POSTAL TRANSPORT AND TELECOMMUNICATIONS (Source: Chamber of Commerce and Industry of Serbia - the largest operators:PE Post of Serbia , Telekom, Telenor, VIP mobile, SBB.

Transportation accounts for about $15 \%$ of Serbia's GDP, which means that this sector is an important part of the economy. About 6,500 enterprises are registered in the field of transportation, employing 124,000 employees, which represents $11.21 \%$ of the total number of employees [3].

Intermodal transportation in Serbia is at an early stage of its development. The infrastructure of the railway and ports - Belgrade, Novi Sad, Pančevo and Prahovo is only partially built. Under national ownership there are only about 1,000 containers, 200 railcars and 100 road vehicles that generally do not meet the standards for international transport. Therefore, intermodal transport in Serbia accounts only for $0.5 \%$ of overall transport, while in the EU the share of this type of transport amounts to about $9 \%$.

The length of road network per number of inhabitants in Serbia is 2.5 times smaller in comparison to the EU countries. (5,500 km/mil inhabitants). In terms of density of road network per area of the territory, Serbia has three times fewer roads than the EU. (500 $\mathrm{km} / 1,000 \mathrm{~km}^{2}$ ).

The Statistical Yearbook for 2016 states that the national fleet consists of slightly more than 9,000 buses, 53,000 mopeds and motorcycles, 140,000 freight carriers, 14,000 towing vehicles, 40,000 auxiliary vehicles and 7,000 official vehicles. The number of passenger cars is close to $1,800,000$, i.e. about 240 per 1,000 inhabitants (virtually the entire population of Serbia can be 
transported by passenger cars in one round), which is, certainly, much lower than in the developed countries, where there are 500-600 vehicles per 1,000 inhabitants.

It should be noted that, if the plans for the construction of highways were realized, it would be possible to redirect the flow of goods and passengers from the western part of Romania through Vršac and Belgrade to Italy and the Adriatic. Similarly, a part of transport could, more easily and efficiently, through Serbia, reach the port of Bar and the Adriatic Sea via the route Sofia-Niš-Pojate-Požega-Bar. The connection with Bosnia and Albania (highway Niš-PrištinaDurres and Bar-Durres) would also redirect a part of transportation through Serbia.

The speed of railway transport in Serbia is still low. The allowed speed limit exceeds $100 \mathrm{~km} / \mathrm{h}$ on just $3.2 \%$ of the railroad, while on the largest part (about $50 \%$ ) of the rail network a maximum speed of up to $60 \mathrm{~km} / \mathrm{h}$ is allowed [24].

In 2015 , there were 748 passenger railcars $(45,000$ seats) and 8,486 freight railcars (carrying 432,000 tons) in Serbia. The power of locomotives is $892 \mathrm{MW}$. The availability of everything is approximately one third lower than in 1990 and quite obsolete.

The railway network of Serbia is connected with railway networks of 7 neighboring countries. There are plans for the construction, modernization and rehabilitation of 874 $\mathrm{km}$ of railway infrastructure, as well as procurement of new and overhaul of existing trains, locomotives and railcars. This refers to the railroad on Corridor 10 and railroad to Bar with the aim to revert it to the design parameters, especially in terms of speed. The construction of the Belgrade-Budapest double-track railway has been announced with a speed of up to $200 \mathrm{~km}$ per hour. The extension of the fast track from Belgrade to Thessaloniki is also planned. Electrification and modernization of the Niš-Dimitrovgrad railroad, construction of the railway bypass around Niš, as well as the continuation of the construction of the railway station BelgradeCentre (Prokop) should be expected.

Similarly, when it comes to roads, in order to redirect a part of transport and trade to its territory, in addition to what has already been mentioned, Serbia needs to invest a lot of efforts into the modernization and construction of the Belgrade-Timisoara and Belgrade-Doboj-Sarajevo (B\&H) railways.

There are 9 ports in Serbia (the most important ones are: Belgrade, Pančevo, Novi Sad and Smederevo). The common characteristic of all our ports is the low utilization of existing capacities, i.e. about $30 \%$ on average. The Port of Pančevo, besides Duisburg, has the most favorable position for operation and development of a port on the Danube. There are plans to invest in the development of a port near Belgrade, as well as the development of the Port of Smederevo in order to facilitate the work of the Steel mill.

Yugoslav River Shipping Belgrade is one of 5 largest shipping companies on the Danube and the largest in our country [25]. It has 100 vessels for the transport of various types of goods including oil and petroleum products. In total, 184 freight vessels have been registered in Serbia with a capacity of 184,000 tons out of which 28 are pusher boats and tugboats.

In regard to inland water transport, we should not neglect the fact that via the Danube Serbia has the exit to the Black Sea in the ports of Reni and Constanta. The Danube has the status of an international waterway.

At present, the river Danube is used as a transportation route for transport of all raw materials for Smederevo Steel mill in Serbia, and also for shipment of a large part of its products. Traditionally, smaller volumes of fuel used to be transported by the Danube to 
Serbia, especially during the sanctions. Also, certain quantities of oil products exported from Serbia are transported through the ports of Reni and Constanta.

Air Serbia [26], as the most important national company, currently owns the fleet of 22 aircraft while 10 airplanes have been ordered. Private airlines also have fleets. The total number of registered passenger seats in Serbian airlines is slightly below 2,000, and the cargo load capacity is around 700 tons. Unfortunately, Serbia has 3 aircraft/million inhabitants, while the EU average is 13 aircraft/million inhabitants.

Current development plans in this area include improvements at Niš and Morava airports.

\section{Telecommunications}

According to RATEL's data for 2014, the number of equivalent lines in 2014 amounted to about 2.85 million [27]. The total number of mobile phone users at the end of 2014 was 9.34 million, which exceeds the total number of inhabitants. The number of internet subscribers in 2014 amounted to almost 6.2 million, which is about $8 \%$ more than in 2013. According to these records, there is an increase in the number of internet and mobile users unlike the landline and cable television, where the number of users of these services has been declining in recent years. In $2015,66.3 \%$ of the Serbia's population and $99.1 \%$ of companies were using the Internet, which is lower than the EU average, i.e. 81\%, but higher than the EU economy, where the average Internet use in companies amounts to $97 \%$ [1].

In $2015,78 \%$ of all households in the EU had access to broadband Internet lines, while the figure for Serbia was $56 \%$. Serbia also strives to reach the EU target in terms of Internet speed of around 30 Mbps by 2016 and 100 Mbps by 2020.

At present, the network fiber optic cables mounted on the OHL network of about $6,000 \mathrm{~km}$ in total length, which could be used for the set-up of a national broadband network, are underutilized. The Serbian academic network, at present, has infrastructure spanning of 50 cities. However, currently only institutions of higher education are connected to it, but it could be the basis for its development.

At present, there are about 120 TV and about 250 active radio stations. In addition to the improvement of communication connectivity across the country and creation of opportunities for widespread use of advanced services in the field of e-business, it is necessary to pay attention to the development of a network that would enable undisturbed transmission of TV, radio and other signals in case of electronic interference and destruction of individual hubs. This is important given the experience with the planned destruction of TV and radio stations and transmitters during the NATO bombing in 1999. A similar situation can be caused by natural disasters, so this is necessary for the sake of continuous, true and timely information flow and warning of the population.

\section{Storage facilities in Serbia}

The Republic of Serbia has a storage capacity of just over 4.3 million tons, while estimates show that the country needs about 10 million tons of storage space. According to the Census of Agriculture 2012, the total number of silos in Serbia was 5,677 (400 large), 10,539 drying kilns and 2,162 cold stores. Some storage capacities are existing and some are currently being built for all types of goods including petroleum products and pallet warehouses. Serbia currently 
owns about $300,000 \mathrm{~m}^{3}$ of storage capacity for petroleum products (out of which Petroleum Industry of Serbia owns about $200,000 \mathrm{~m}^{3}$ ). However, it lacks the capacity for the storage of oil products such as emergency oil stock in the amount of about $300,000 \mathrm{~m}^{3}$.

The Directorate for Commodity Reserves of the Republic of Serbia is the Central Stockholding Entity for all necessary commodities. The Directorate maintains the stocks of oil and oil products, food, medications, materials for defense purposes, etc.[19].

\section{Logistics resources}

\section{Monetary-financial resources}

According to the Report on the banking sector in Serbia [2], 8 national and 21 foreign-owned banks are registered. The total capital of banks amounts to about EUR 24 billion. The ownership structure in the insurance sector is similar.

Household savings are at the level of EUR 8.7 billion. This practically means that each citizen of Serbia has savings of somewhat more than 1,200 EUR on average. At the same time, the level of household credit debt is one of the lowest in Europe [1].

The government budget is slightly less than EUR 9 billion (RSD 1,117,597,581,000 for 2016). Budget expenditures have been higher than income for many years. The highest expenditures are for salaries of employees - $22.5 \%$, pensions - $19.6 \%$, subsidies $-7.75 \%$, interest on loans $-12.5 \%$, social welfare $-10.4 \%$, use of goods and services $-8.6 \%$, repayment of principal $-3 \%$, transfers to municipalities and cities - $3 \%$, etc. The previous shows that the budget is socially oriented (about $87 \%$ of revenues are spent on "preserving status quo").

Serbia's foreign exchange reserves are at the level of EUR 9-12 billion depending on the policy of the National Bank at certain points (today slightly over EUR 7.5 billion belongs to the National Bank, and the rest are required bank reserves). Even though it can be said that these reserves provide coverage of money supply by more than $200 \%$ and for six months of imports of goods and services, the question remains how big the amount that would be available in an emergency situation is since the money supply is either bound by long-term contracts or could even be subject to sanctions and bans. It should be kept in mind that potential non-ability to "cover money supply" can result in a drastic decrease in the value of the local currency, which is the scenario that has been repeatedly seen in recent history.

Military expenditures have been in the range of $1-2 \%$ of GDP for years. In developed countries and countries with stronger armed forces allocations for defense are at the level of $2-4 \%$ of GDP.

In emergency situations, such it was in 1999, the allocation for military and security forces could be increased by more than double by introducing additional taxes (in 1999 an additional VAT of $3 \%$ was introduced). That could be the maximum amount available in emergency situations, which is at the level of the present Croatian military budget and less than the Bulgarian military budget.

Human resources

The share of working age population in Serbia is in the range of 2.8 to 3.3 million. Agriculture accounts for $24-30 \%$, industry $27-46 \%$ and service sector $24-50 \%$ (data from different sources vary). 
The 2011 Census data shows that the decline of population trend continued (by $4.2 \%$ between two censuses) and increase in average age (42.2 years).

About $34 \%$ of the population is at the basic educational level or below. A positive trend is shown by the number of inhabitants with the secondary education, as well as with the first and second level of tertiary education, with a simultaneous drop in the share of the population with an educational minimum.

Serbia (based on life expectancy of 73.7 years and the current level of GDP) is in the group of middle income countries with a high level of human development (HDI index 0.735).

Given the existing (insufficient) demographic potential, Serbia needs to put in longterm efforts in order to develop the "human capital" infrastructure, which is a critical factor for sustainable economic growth and improvement of the quality of life. In line with such development is also the estimation that human resources in Serbia are not the decisive factor of national competitive ability, i.e. that they do not represent a sufficient comparative advantage.

In regard to the vocations that are particularly important for the military and security sectors, there are about 20,000 licensed engineers in Serbia (according to the data of the Serbian Chamber of Engineers). It is estimated that around 5,500 students annually enroll in IT studies. Currently, around 12,000 scientists and researchers work in Serbia, and about 240,000 students are being educated. Unfortunately, the structure of fields of study is also unfavorable because in some of the fields, particularly the technical one and mining, there are almost no students enrolling.

Serbia has a significant human resources potential, which is university-educated and trained to perform various logistical jobs and tasks. Such resources are educated at the Faculty of Transport and Traffic Engineering - University of Belgrade and the Military Academy.

Another source of human resources trained for the majority of jobs in the area of defense and security are private security companies. According to the data of the Serbian Chamber of Commerce, there are currently 314 companies in this field employing 274 people. These organizations can serve as a significant source of staff and information, and they can perform certain security tasks either independently or in coordination [3] (according to some sources this sector employs between 40 and 60,000 people).

\section{Agriculture and forestry resources}

Agricultural land area amounts to $5,734,000$ hectares ( 0.56 ha per person), out of which about $4,867,000$ hectares are arable land ( 0.48 ha per person). About $70 \%$ of the total territory of Serbia is agricultural land, while $30 \%$ is under forests.

Serbia is ranked 17 th out of 206 countries and territories according to the surface of arable land per person, with 48 ares, which is more than double the world average and the highest level in the region. The highest-ranked countries are large-area countries with low population density: Australia, Kazakhstan, Canada, Argentina, Niger and the Russian Federation. It is interesting that the USA are ranked 14th with 51 ares per person [4]. These relative ranks are corrected by other factors: land cultivation intensity, soil quality, land plot size, etc.

The total agricultural area ( $0.54 \mathrm{ha})$ and the used agricultural land per person $(0.48$ ha) are relatively satisfactory for the food self-sufficiency of the population in Serbia (it is estimated that 0.2 ha per person is necessary for food self- sufficiency) [4]. 
The main agricultural products of Serbia are corn (about 7-8 million tons per year), wheat (about 2-3 million tons per year), sunflower (about 0.5 million tons per year), sugar beet (about 3.5 million tons per year) soybeans (about 0.5 million tons per year), potatoes, fruit and grapes (about 1.3 million tons), vegetables (about 1.7 million tons per year), pork, beef and poultry meat (about 6 million of headage, and around 400-500,000 tons of meat) and milk [3].

The Serbia's production of seed material mostly meets the needs of the national market. Mainly, significant quantities of vegetable seeds are imported.

According to the Census of Agriculture (2012), in Serbia there are 593,378 single-axle and two-axle tractors and 31,241 combine harvesters. Revitalization of agricultural machinery is worth USD 10-15 billion. Serbia has significant livestock processing capacities $(1,176$ facilities for slaughtering and processing meat of cattle, pigs, poultry and fish).

In regard to forestry, as a raw material basis for wood processing, it should be noted that Serbia is among medium reporting countries with a total of $29.1 \%$ of forest area, i.e. 2.2 million hectares of forests. Besides agriculture and food industries, wood industry is the second most important sector in the country and it has a constant trade surplus.

\section{Water resources}

"It is often said that future wars will be fought over water. Therefore, presumingly, countries that are poor in drinking water, and rich in weapons would attack water-rich countries incapable of self-defense. We could simulate future wars by mapping population and drinking water across countries. "[5].

World supplies of drinking water are decreasing and demands are growing. According to the UN data, water consumption will increase by $58 \%$ by 2025 as compared to current consumption, and some countries like Saudi Arabia will completely run out of the water. There is an interesting case of Lesotho, the country whose main export product is water. Namely, rivers that had been naturally flowing into the Indian Ocean were rerouted via an underground tunnel in order to fill artificial lakes in South Africa, which does not have its own water resources sufficiently.

Serbia, including Kosovo ${ }^{1}$, accounts for $0.3 \%$ of world drinking water resources, while it accounts for $0.13 \%$ of world population and has $137 \%$ more drinking water per person than the world average. According to the UN classification in regard to the reserves of healthy and drinking water, Serbia is ranked 47 th. "In the region, only Croatia is $30 \%$ richer in drinking water than Serbia. In Europe, only Iceland, Norway and Russia are richer in drinking water than Croatia. Beyond that, Sweden and Finland are also richer in drinking water than Serbia. "[6] Germany, France, Italy, Turkey, Bulgaria and Macedonia lack water resources.

Serbia's water resources per person amount to 1,500-2,000 m3 [7,8], out of which $8 \%$ are domicile and $92 \%$ transit waters. Accordingly, Serbia belongs to the group of "vulnerable countries" in terms of availability of the resource, i.e. Serbia is ranked at the borderline between the countries having sufficient water resources and those where they are relatively scarce.

\footnotetext{
${ }^{1}$ In the text the official name Kosovo and Metohija is replaced with Kosovo to bring it closer to the English readers. Authors fully respect the official name and have no political intentions in that regard.
} 
Serbia, however, is at the very top of the list of countries rich in high quality mineral water [9]. The total production of all mineral water bottling plants is over 400 million tons a year and about 10,000 people are employed in water plants in Serbia (300-400 sources and about 30 bottling plants). This branch of the economy records permanent growth. The significance of this is best shown by the data provided by the Ministry of Mining and Energy according to which nine of ten applications for licences in the area of exploration of mineral resources are submitted specifically for the exploration of mineral groundwater [10].

On average, the population of Serbia consumes about 300 liters of water per day, while in Europe this consumption is between 120 and 150 liters of water [11]. Such data illustrates that the water resources are being used irrationally, primarily because of low cost, but it also signals to potential savings. However, the quality of water is a large concern since $30 \%$ of water supply and watercourses have maintenance issues.

\section{Industry and mining}

The field of industry and mining includes the extraction of ore and stone, the processing industry and the production and distribution of electricity, gas and water [3].

\section{Mining}

Except for copper, antimony, lithium, lignite and some basic non-metals (magnesite, limestone, dolomite, calcite, quartz sand, construction gravel and sand, ceramic and refractory clay, gypsum, borates, zeolites, anhydrite and phosphates), the raw material base for the development of the mineral industry in Serbia is insufficient, both in terms of quality and exploration level. Taking the territory of Kosovo into account the situation improves due to lead and zinc, chromium and nickel ores, especially the fifth largest reserve of lignite in the world. From the point of view of the mining industry, newly discovered deposits, which were unknown until recently, could be highly significant. These are: lithium, borates, wollastonite, zeolite, phosphorus and fluorite.

According to experts' speculations, there is a possibility of 5 and 10 new mines to be opened in Serbia. It is the fact that a world - class mine can contribute to the increase of GDP by several percent, while a few large mines could completely change the outlook of the Serbian economy.

It is likely that Ćirkovac lignite mine near Kostolac and Štavalj brown-coal mine near Sjenica are likely to be opened. In comparison to the demand, Serbia produces a negligible amount of hard coal in Ibarski rudnici in its territory. There is hope that the hard coal mine Jerma near Babušnica will soon be rehabilitated, as well as the somewhat smaller mine llino brdo near Rtanj. Considering that there are plans for the construction of a petroleum coke production plant within Pančevo Refinery, together with the production of hard coal from new coalmines, Serbia will have an opportunity to meet its own needs for hard coal and coke (up to 1.5 million tons), which is a strategic raw material for the production of iron and steel in the Steel mill Smederevo. Unfortunately, Serbia does not have a plant for the production of coke (from coal) in its territory. The closest plant is located in Lukavac $(B \& H)$, which was designed to meet the needs of former Yugoslavia for this material. 
Steel accounts for $50 \%$ of all technical materials and $10 \%$ of total demand for raw materials in the world. Therefore, it represents one of the most important raw materials for the economy, especially for the machine industry and construction. The nearest iron mines for Serbia are located in the Republic of Srpska, more precisely in Ljubija. The amount of iron ore obtained in that mine should meet the capacities of the Still mill in Smederevo. Within the region, there are several additional smaller iron mines in the Federation of B\&H and Macedonia.

A special group of ores consists of alloy steel elements, which are used to improve certain characteristics (conductivity, elasticity, corrosion resistance ...). Most important alloy steel elements include chrome, manganese, molybdenum, nickel, cobalt, cadmium and tungsten, and some non-ferrous metals such as copper or zinc. Alloy steel elements (manganese, chrome, titanium, vanadium, nickel, molybdenum) are mainly imported into Serbia.

Molybdenum is a rare and valuable metal, whose deposits in Serbia are still in the stage of exploration (the mine near Surdulica was in operation during the Second World War).

Nickel deposits in Serbia are significant and widespread: Stragari, Kadina Luka, Ba, Željin, Stolovi and Kosovo (Uroševac, Orahovac, Goleš, Kosovska Mitrovica). Despite significant reserves and proven profitability, the opening of a nickel mine in Serbia is questionable due to public opposition because of adverse environmental impact of the mine.

Bor used to be the largest copper mine in Europe. The secondary extraction of precious metals from copper ore is also significant. After the latest explorations carried out by the US companies around Bor, it can be said that a new copper mine, and one of the largest in the world, with high-grade gold ore, could be opened soon.

Aluminum ore (bauxite) has been detected in Kosovo, but it has not been exploited yet. The imported aluminum is processed in the Copper Mill in Sevojno near Užice. The nearest bauxite sites in the region are located in the Republika of Srpska and Montenegro.

In Serbia, without Kosovo, lead is exploited (together with zinc) only on the mountain Rudnik.

Antimony belongs to a group of rare metals. Serbia has reserves of this ore, which are internationally significant.

Magnesium is also a rare and important metal. The most important mine is located in Baljevac, being the only such mine in Europe.

Lithium is an extremely light metal, which is used today for the production of lithium batteries that are being increasingly used in the automotive industry and energy sector. The deposits of this metal in Serbia are of a more recent date and are related to the deposits of a newly discovered mineral Jadarit. Serbia can meet about $20-30 \%$ of the world's demand for lithium.

A profitable borate deposit was discovered in the Ibar valley near Baljevac.

Currently, a phosphate mining project at Lisina, near Bosilegrad is being developed for some time - a primary raw material for the production of phosphoric acid and mineral fertilizers. Considering the fact that the nearest deposits of phosphate ore are located in the north of Finland and the North African Belt, Lisina is of the exceptional strategic importance, as the only significant deposit in continental Europe.

Gold is an important and expensive metal, and one of the gold mines - Lece mine, is located on the Radan mountain. Silver in Serbia is mostly co-produced with lead and zinc.

Serbia has internationally significant reserves of zeolite ore. "Nemetali" V.Banja can produce zeolite tuff and bentonites. 
In Serbia, approximately 200 mines actively produce non-metallic mineral raw materials. To various extents, 48 raw materials have been explored, out of which 16 are continuously exploited, 16 are exploited occasionally, while 16 raw materials are insufficiently explored and are not exploited either.

Despite general decline of the industrial production in Serbia, the construction materials industry represents a significant and profitable branch of industry, which is based primarily on non-metallic mineral raw materials, i.e. mining. These are the cement factories in Beočin, Kosjerić and Novi Popovac, the brick industry in Kikinda, Novi Bečej, Novi Pazar, Ruma, Kanjiža with about 300 brickyards,etc. Exploitation of technical and architectural stone takes place in open pit mines near Ub, Topola, Jelen Dol, Arandjelovac. We have sufficient stone reserves for meeting building-technical needs, while the reserves of decorative stone are scarce.

In economically developed countries, the value of total annual production of nonmetallic mineral raw materials has exceeded the value of metals obtained in the same countries long ago. In some cases, this difference is 1.5 to 10 times in favor of nonmetals. A reverse ratio (when the value of the obtained metals exceeds the value of nonmetals) is considered to be a characteristic of countries with colonial or semi-colonial economies [12].

\section{Industry}

Industrial production is at $40 \%$ of the one before 1990 . It accounts for $19-25 \%$ of GDP. However, it should account for at least $30 \%$ if we compare ourselves with the fastest growing economies today. The average age of the machinery park is 20-35 years. The share of low-tech industries amounts to $50 \%$, while the share of medium-low technology industries is $27 \%$.

The most important export products are cars, hulls and military equipment. There are limited possibilities for the production of trucks, locomotives, railcars, hydraulic equipment, equipping of ships and production of light aircraft. The production of tractors and combine harvesters is almost completely diminished despite potentially high market demand in the future.

The company EI Niš has gone bankrupt, so virtually the entire production of home appliances in Serbia has stopped except for some plants for the assembly of Gorenje appliances. MINEL from Belgrade, which produces almost all types of transformers and other electrical equipment, is in pre-bankruptcy stage.

As the "electrical engineering" industry is concerned, the production of cables, pipes and other products based on copper and aluminum still partly survives owing to availability of national or raw material base in the immediate vicinity.

The metalwork and electrical sectors are always concentrated on large systems that gather clusters of subcontractors around them. The lack of such systems and subcontractors today is a huge obstacle to revitalization of the sector.

The national chemical industry is import dependent (about $80-90 \%$ of raw materials are imported), but also export-oriented. The largest exports, as well as imports, are present in the field of manufacturing plastics and plastic products. It should be noted that Serbia imports 
cement (for USD 100-150 million), fertilizers, and particularly urea (for over USD 220 million), rubber (about USD 300 million) and glass and ceramics (for more than USD 200 million).

The production of inorganic (artificial or mineral) fertilizers is of key importance for agricultural production. The basic raw materials for the production of fertilizers are natural gas, sulfuric acid, phosphates and phosphoric acid, ammonia, nitric acid, magnesium, etc.

In order to achieve yields at the European level, we need to use nearly 300 kilograms of fertilizer per hectare. It is estimated that we lose at least 3 (if not twice as much) billions of dollars a year because of the sub-optimal fertilization of land.

According to the Statistical Office of the Republic of Serbia, the production of artificial fertilizers and nitrogen compounds in 2015 amounted to 815,263 tons, which is twice less than in the 1980s and far below the installed capacity.

It should be noted that Serbia does not have all raw materials required for the production of artificial fertilizers inits territory, i.e. phosphates and natural gas. The production of sulphuric acid is largely conditioned by operation of the Bor mine, i.e. in case the operation stops, one of the most important sources of acid is interrupted. The issues in regard to the supply of natural gas could be overcome by establishing a certain level of strategic stocks of natural gas, which is possible under current conditions. The opening of a phosphate mine near Bosilegrad would completely change the situation, perspectives and possibilities of producing NPK fertilizers for the better.

In Serbia, powder and liquid detergents are produced in the Henkel plant in Kruševac, Beohemija in Belgrade and Aktavis (formerly Zdravlje Leskovac).

There are several manufacturers of car tyres in the country. The most prominent ones are Trayal from Kruševac and Tigar Pirot. They practically produce tyres for all types of vehicles. Trayal also produces agents for chemical protection. Certain types of explosives and anti-hail rockets are also produced in this plant.

In Serbia, there is a large number of undertakings that are engaged in manufacturing plastics including packaging, construction plastics and car covers and tents. There are almost no plastic products that are not being or could not be manufactured in Serbia.

The situation in the Serbian glass industry is such that all three plants, in Paraćin, Zaječar and Pančevo are under bankruptcy or pre-bankruptcy.

Lube oils and lubricants are produced in Serbia at one plant in Novi Sad Refinery, Oil Refinery Belgrade and FAM Kruševac. In these plants, Serbia can produce almost all types of lube oils and lubricants that military technology requires. The future of these companies and production programs is currently uncertain.

\section{Production of weapons and military equipment}

In terms of export value, arms and military equipment reached the level of USD 755 [13] million in 2014 and became ranked as one of the top industries alongside the export of steel and petrochemical products in Serbia. Serbia is ranked somewhere between $15^{\text {th }}$ and $20^{\text {th }}$ place in the world according to the export of weapons and military equipment [14].

The production of arms and military equipment in Serbia [15] includes the following products: multiple rocket launchers, self-propelled artillery, tactical rocket systems up to $50 \mathrm{~km}$ range, systems for surveillance of battlefield and areas, CBRN equipment, lightweight $60 \mathrm{~mm}$ mortars, uniforms and footwear, bullet-proof vests, all types of rifles, 
pistols and machine guns, light AD systems, artillery command combat systems, optical and optoelectronic equipment, quartermaster equipment (mobile kitchens and other), offroad vehicles, several types of combat vehicles, several types of upgrades for combat vehicles including tanks, guided and unmanned rockets and grenades, airborne containers and weapon carriers, unmanned aircraft, school planes, parachutes, light vessels, electronic warfare equipment, power generators, mines, multiple types of infantry and artillery ammunition and bombs, landmine detector robots, firefighting and protective equipment, special purpose oils and lubricants, as well as overhaul of a large number of models of weapons, military equipment and ordnance.

The most important entities that are engaged in the research, development, production, equipment and overhaul of weapons and military equipment in Serbia are the Military Technical Institute - Belgrade and Technical and Aviation Test Center. Arms and military equipment manufacturers consist of 45 companies in Serbia [16]. Additional 3 overhaul institutes should be added to this group.

Considering the abovementioned it is possible to conclude that Serbia can meet its own demands for all types of infantry weapons, protective equipment and necessary ample ammunition. Production of some highly sophisticated systems such as armored combat vehicles, missiles or unmanned aerial vehicles is also possible. The production of other types of weapons depends on the import and economic standing of a manufacturer.

\section{Construction industry}

In the past, the construction industry used to be one of the most expensive and propulsive export industries. Despite all its advantages, it would still not be able to meet the entire demand in emergency situations without being provided with the supplies of raw materials and intermediate goods, especially asphalt.

\section{Manufacture of clothes and footwear in Serbia}

In the period from January to June 2013, the value of Serbia's footwear export was nearly USD 159 million, and at the same time the import value of the same product amounted to USD 11 million. The surplus was generated by manufacturing approximately 2 million pairs of footwear [17]. The leather manufacturing industry of Serbia is export - oriented. However, when the chemicals, which are used for leather tanning, finishing, dyeing etc. are concerned, Serbia is import-dependent. Serbia has significant resources of raw and fine leather, as well as pigskin leather, which is of exceptional quality and there is a high demand for it. In terms of quality, particularly exceptional is "baby beef" leather. Additionally, all kinds of ready-made leather, which have wide application in the garment industry, furniture industry, etc. are produced.

In 2015, Serbia exported USD 1 billion worth of clothes and it was ranked 18th on the list of the EU textile suppliers. The raw material base in Serbia is very poor. Therefore, $79 \%$ of wool, $95 \%$ of cotton and $100 \%$ of jute are imported for the needs of national production [18].

It could be concluded that in emergency situations Serbia would meet the needs of its population and the armed forces in clothing and footwear provided that the supplies of raw materials were secured. 


\section{Healthcare resources}

According to the data of the Health Insurance Fund of the Republic of Serbia, there are 158 medical centers, 77 hospitals (40 general hospitals and 37 special hospitals), 6 clinics; 4 clinical centers (Belgrade, Kragujevac, Niš and Novi Sad) and 29 institutes (for public health, forensic medicine, transfusion, etc.) with 38,875 hospital beds in Serbia. These entities employ 20,645 medical doctors, 2005 doctors of dental medicine and 2,186 pharmacists [21].

The private sector includes 1,020 medical practices, 2,000 pharmacies, 2,500 dental practices, 200 laboratories, 155 polyclinics, 18 health centers, 12 general and 76 special hospitals, as well as 5 radiological diagnostic institutes. The private sector permanently employs 4,233 medical doctors alongside about 7,000 part-time doctors [20].

It could be said that every municipality in Serbia has a medical center or at least a sort of medical practice, and that on every two or three municipalities there is one hospital. This means that the coverage of the territory by medical care is satisfactory. An important indicator is that on 100,000 inhabitants there are 289 medical doctors, 28 dentists and 31 pharmacists in the public sector of Serbia [21].

According to the IMS data for 2015, the market for medications in Serbia amounts to cca EUR 788 million. In terms of quantity, national medications account for $62 \%$, and imported ones for $38 \%$ (in terms of financialvalue the situation is reverse). Hospital and state pharmacies distribute about $52 \%$ of the total amount of medications, and the rest is distributed by private pharmacies. The largest manufacturers of medications are Hemofarm, Zdravlje and Galenika (more than 95\% of national production). The value of medications export is over USD 212 million, and imports amount to about USD 185 million.

The previous considerations lead us to the conclusion that in the event of a crisis or emergency Serbia would have sufficient healthcare capacities. The availability of equipment is also at a satisfactory level. The problems could arise in the supply of medications from import and the maintenance of equipment.

\section{Residential and accommodation resources}

In Serbia there are 3,243,587 housing units according to the 2011 census [22]. Practically, there is one apartment of $72.3 \mathrm{~m}^{2}$ floor area per 2-3 inhabitants on average. There is the total of 2,423,208 apartments in use, i.e. $80.4 \%$ of apartments intended for permanent dwelling. It is important to note that, according to the Ministry of Finance, 318 categorized hotel-type facilities operate in Serbia with 29,440 beds. These facts confirm that Serbia has the sufficient number of housing units for accommodating the armed forces under an irregular (practically guerrilla) schedule. This conclusion was also reached on the basis of the studies conducted after the NATO bombing. The number of apartments, accommodation units and beds in hotels is significant from the point of view of providing accommodation for the army members and displaced persons in emergency situations.

\section{Potential of Information and Communications Technologies - ICT Industry}

According to the data of Microsoft Serbia, in 2011554 companies in the IT sector with about 6,000 employees (if employees in the field of manufacturing calculating machines and telecommunications are included that number amounts to 15,000) generated slightly more 
than EUR 200 million of income [24]. Corporate IT departments should be also added here. The number of employees in the IT sector grows at the rate of $23 \%$ per year. This sector is one of the most promising high - tech industries in the country. The biggest increase is recorded in the software development sector followed by companies engaged in the production of computer machines and telecommunications. Today computer manufacturing in Serbia involves the assembly of computer units from imported components and increasingly the production of industrial computers that are used for process control and management.

It is expected that this sector will witness the biggest "boom" given the global orientation towards knowledge societies and the so-called Third Industrial Revolution based on further automation of the process. Military-security terminology has started to include the terms such as 'cyberwarfare' or 'war on the Internet'. Russia and the United States use drones of all sizes for both scouting and tracking of the terrain, as well as for attacks on targets far in the depths of an enemy territory. What has been just said may greatly affect the appearance and content of future wars and security operations in general. Some countries such as Russia and China have already set up special units in order to carry out actions in this field. Everyone has started to fear not only cybertheft or data espionage, but also the situations that would be caused by breakdowns of information systems of banks, stock exchanges, transport systems, etc.

The Serbian specificity is such that for dynamic development to be achieved, it is necessary to educate several times more experts than it is currently the case. Also, national production of computers, phones, sensors, drones and other electronic equipment should be encouraged in every possible way.

\section{Meteorology}

The most important organization in the field of operational meteorology is the Hydrometeorological Service of the Republic of Serbia (RHMSS). The operational department of RHMSS is responsible for the efficient implementation of anti-hail systems, the integrity of technical equipment and network of anti-hail stations with radar centers, supply of anti-hail rockets, etc. It is interesting to note that the meteorological service of the Republic of Serbia has never been under sanctions.

\section{Veterinary Medicine}

According to the available data, there are about 150 veterinary stations (in 150 citiesmunicipalities) with about 700 veterinarians in Serbia. These numbers are potentially even higher, but the authors could not check them. Most of the veterinary stations in Serbia have been privatized and are in an unenviable state. The possibilities of this service are limited, and practice is lagging behind the ones in the developed countries except in the case of dogs and cats.

\section{Energy}

The annual demand for primary energy in Serbia excluding Kosovo and Metohija in 2013 was approximately 14.9 million tons of oil equivalent. The high share of national lignite (over 50\%) enables relatively high (in comparison to other countries) energy independence of the country and electricity generation with relatively low and stable costs 
( $75 \%$ of electricity produced). On the other hand, the use of lignite increases the impact on the environment. This fact, in the long run, also increases the risk of increased costs of carbon dioxide emissions, i.e. gases that globally cause the greenhouse effect.

In 2013 , Serbia's energy net import dependency amounted to $24.1 \%$, which is lower than in the vast majority of European countries (EU 54\%). Import dependence has been reduced mostly due to the increased national production of oil and natural gas. In 2014, the costs of net energy imports amounted to EUR 1.76 billion. Serbia is ranked fourth least dependent on foreign energy sources country in Europe. This result should nevertheless be considered in the context of the industrial production being reduced to one half as compared to 25-30 years ago.

Unlike coal, about three-quarters of oil and oil products and four-fifths of natural gas are supplied from abroad. At the moment, the majority of imported gas is supplied from Russia, and there is the tendency of developing total dependency on Russian gas. The similar situation is with oil and oil products (the share of crude oil and gas produced in Serbia will decline in the coming years due to the depletion of national deposits). Currently Serbia depends on imports of gas from Russia, as it is connected to the pipeline system from Russia. Oil can also be obtained from other sources.

The largest oil and gas reserves were discovered in Vojvodina, while somewhat smaller reserves were found in the Danube and Morava river basin. Oil shale deposits have been best explored in Aleksinac and Vranje basin, but at present there are no available economical technologies for processing. Potentially, about 600,000 tons of shale oil in Aleksinac basin can be obtained from oil shale, but this technology is cost effective only at high prices of crude.

Article 267 of the Criminal Law of the Republic of Serbia prohibits any construction of nuclear facilities, and Serbia is the sixth country in the world that has removed highly enriched uranium from its territory. Accordingly, systematic geological exploration of nuclear mineral resources (uranium and thorium) was interrupted.

Considering other energy products, the most important ones are hydropower and biomass, i.e. wood (together they account for about one-eighth of the primary energy consumption).

A significant issue is that the consumption of primary energy per unit of GDP in Serbia is $15 \%$ higher than the world average and almost twice as high as in the European OECD countries. This illustrates low energy efficiency.

A significant difference in the structure of final energy consumption, as compared to the European Union, is Serbia's high share of household consumption and lower share of energy consumption in the transportation sector than in the EU. At the same time, it should be born in mind that the industrial production in Serbia is significantly lower than at the end of the 1980s. Accordingly, it can be concluded that in the event of an energy crisis, Serbia could provide sufficient energy for the sectors of transportation and agriculture, while electricity rationing would mostly affect the industry and the population.

It is estimated that the share of imports within the final consumption of energy for the following decades will be slightly increased and that, in accordance with the Energy Strategy of Serbia, it will reach $37.4 \%$ in 2030. According to the 2014 World Energy Outlook estimates, it is expected that by 2040 the demand for primary energy will increase by $37 \%$, with natural gas consumption increase of $50 \%$ and oil consumption of $10 \%$. 
These trends will have unfavourable consequences for Serbian energy security. The estimation in the 2014 Energy Strategy of Serbia is that the import dependence on natural gas will be as high as $97.6 \%$ in 2030 , while imports of oil will reach more than $90 \%$ of total consumption due to the depletion of national reservoirs.

In order to reduce Serbian energy dependency, it is necessary to fulfil several conditions: to increase energy production from its own sources (primarily from hydro and other renewable sources), change the structure of energy consumption, especially by reducing gas consumption and irrational energy consumption (energy efficiency). In the transportation sector, electrification of the railways, as well as the introduction of electrically powered vehicles and national biofuels can generate significant effects. All of these measures will not change the fact that Serbia, despite the progress achieved so far, will remain highly dependent on imports of oil and to a lesser extent on imports of natural gas. The situation could be somewhat changed by the exploitation of oil shale for which Serbia has the potential and by establishing larger stocks of oil products and gas. The developed countries tend to resolve the issue of shortages of oil and gas by acquiring concession rights to these resources in the less developed countries through their oil and gas companies. Unfortunately, Serbia has acquired only one small-scale concession in Angola so far.

(Un)fortunately, depending on whether it will be implemented, Serbian greatest energy resource lies in the potential raising of its low energy efficiency level. While the developed countries consume less than $100 \mathrm{kWh}$ per square meter, Serbia consumes between 150 and $180 \mathrm{kWh}$. Out of the total energy consumed, almost one half accounts for household consumption, out of which even $60 \%$ is used for heating. The latter points to the development of a possibility of heating based on solar energy and other renewable sources for which Serbia has the potential.

In Serbia, there is one pumped hydroelectric storage HPP (Bajina Bašta) of $307 \mathrm{~mW}$, which is also highly important for the operation of the system.

By OHL networks, Serbia is connected to all neighbouring countries and represents a kind of a power hub. By increasing the transmission capacity and construction of an undersea connection between Montenegro and Italy, the importance of Serbia as the country through which power is being transmitted will only grow.

The development of the market for oil and oil products is largely impacted by the Law on Commodity Reserves ("Official Gazette of the Republic of Serbia", No. 104/13), which transposes the Directives 2006/67/EC and 2009/119/EC related to the provision of minimum emergency stocks of oil and oil products to the national legislation. This Law stipulates that by 2023 Serbia will provide stocks of oil and oil products in the amount of 61 days of average annual consumption.

The Directive 2009/28/EC, which refers to the mandatory share of biofuels in motor fuels in order to reduce the greenhouse gas emissions, has not yet been transposed to the national legislation. According to the Renewable Energy Action Plan a commitment to achieve $10 \%$ of the share of biofuels in motor fuels by 2020 has been undertaken, but the share of biofuels in the oil product market is still negligible.

Oil transport is carried out mainly by the oil pipeline that starts in the Adriatic port of Omišalj. It enters Serbia in Bačko Novo Selo and continues to extend through Novi Sad to the refinery in Pančevo. A smaller share of oil imports is carried out by barges on the Danube, and national crude oil is transported by tank trucks from national oil fields to oil refineries. 
At present, the only underground gas storage, Banatski Dvor, is located inside the depleted gas deposit. The current available capacity amounts to 450 million $\mathrm{m}^{3}$. After the stage two of development, the storage will be able to receive $800-1,000$ million $\mathrm{m}^{3}$. In Serbia, there is the storage capacity of about 6 billion $\mathrm{m}^{3}$ across several storage facilities, among which the most promising ones are Itebej and Ostrovo.

Our country has two interconnections with other gas pipelines (one entry point and one exit point each). These gas pipelines are Hungary-Serbia (Kiskundorozsma) - the entry point and Serbia-B\&H (Zvornik) - the exit point.

\section{Perspectives}

It is not difficult to conclude that the development of economy has a favourable effect on the capacities of national logistics and vice versa. The more production and roads we have the greater capacities for meeting material needs in crisis and war situations are. The development of the economy is therefore crucial for increasing the overall potential of logistics. The greater demand for transport of goods and passengers will condition the development of transport infrastructure, and the development of infrastructure will lower the costs of transport per unit of production and thereby create positive feedback.

When considering the state of the Serbian economy, which has already been elaborately discussed above, we can clearly distinguish several main drivers or generators of development. These drivers of development are determined on the basis of the comparative advantages that Serbia has in these areas in relation to the broader surroundings. An additional argument for their identification was the historical investigation of trends in the Serbian economy for the last century. It is clear that most of what had been developed until 1990 was precisely based on national resources, low national logistics costs and an increase in processing inside the value chain, which generated overall comparative advantages. The existence of comparative advantages facilitates the survival and development, but does not guarantee it because it is necessary to achieve and maintain the competitive ability. The historically confirmed self-sustainability of these areas provides guarantees that the development should be based on them. The acceleration of development in these areas can only be expected with higher investments and state support.

A summary of the drivers of development in Serbia is given in Table 1.

Serbia has the potential to produce agricultural products displaying a clear comparative advantage such as baby beef (cattle breeding in general), berry fruit and fruit and vegetables in general, which are considered as more expensive products from the "extra demand" group that results from the increase in welfare. Serbia has a "surplus" of arable land per capita due to which it is in a position to produce sufficient food for its needs, as well as to export surplus to foreign markets. The increase in agricultural output in a more general sense will reflect on the development of the manufacturing industry, production of wood fuel and biofuels. The new possibilities for revitalizing the production of agricultural machines, especially the already existing capacities, should be added here.

Mineral water is the resource in which Serbia is one of the leading countries in the world. The price of bottled water is up to $25 \%$ of the price of motor fuel, which demonstrates the value of the resource. The biggest issue in regard to the development in this 
area are high transportation costs. The development of the transport infrastructure should open new possibilities in this respect. We should not forget the fact that investments in water supply and wastewater treatment are necessary.

Table 1 - The drivers of development of Serbia based on the analysed comparative advantages, character and technological complexity

\begin{tabular}{|c|c|c|c|c|}
\hline Resources & Infrastructure & $\begin{array}{l}\text { Low Tech } \\
\text { industries }\end{array}$ & Mid Tech industries & $\begin{array}{l}\text { High Tech } \\
\text { industries }\end{array}$ \\
\hline $\begin{array}{l}\text { Agriculture and } \\
\text { animal husbandry } \\
\text { Mineral water } \\
\text { Hydropower } \\
\text { Solar energy, wind } \\
\text { and biomass } \\
\text { Mining: copper- } \\
\text { gold, coal, oil shale, } \\
\text { borates, zeolite, } \\
\text { nickel, phosphates, } \\
\text { molybdenum, lith- } \\
\text { ium (Jadarit), non- } \\
\text { metallic raw materi- } \\
\text { als }\end{array}$ & $\begin{array}{l}\text { Road and rail corri- } \\
\text { dors } 10 \text { and } 11 \\
\text { Telecommunications } \\
\text { Power transmission } \\
\text { Oil pipelines and gas } \\
\text { pipelines } \\
\text { Water supply }\end{array}$ & $\begin{array}{l}\text { Textile } \\
\text { Wood } \\
\text { Footwear } \\
\text { Construction } \\
\text { materials }\end{array}$ & $\begin{array}{l}\text { Power generation } \\
\text { Artificial fertilizers } \\
\text { Steel } \\
\text { Electro-mechanical } \\
\text { Defence industry } \\
\text { Agricultural machin- } \\
\text { ery and vehicles }\end{array}$ & $\begin{array}{l}\text { ICT De- } \\
\text { fence in- } \\
\text { dustry } \\
\text { Lithium } \\
\text { batteries }\end{array}$ \\
\hline
\end{tabular}

Exploitation of copper and gold in the Bor region can result in the survival and development of the cable industry, production of copper pipes and other types of production based on these raw materials. Sulphuric acid, as a by-product of copper refining, provides the raw material for the production of artificial fertilizers, for which there are serious and under-utilized capacities in the country. Opening a phosphate mine would simply enable additional impetus for the development.

It should be noted that steel mills represent incubators for the development of numerous plants that use iron and steel as a raw material such as the factories producing pipes, boilers, structural construction elements, but also the entire machinery and electro-mechanical industry. The factories producing pipes and similar structures have remained in Kosovo and are out of operation, which provides an opportunity for opening new ones in other parts of Serbia. If the Steel mill manages to produce certain types of steel for the automotive industry and other machine industry, it would be possible to revitalize this segment of the economy. The national copper and steel production should provide a good raw material base for the revitalization of electro-mechanical industries such as Minel. The comparative advantages of this branch of industry could be achieved, besides investing in new products, through the revitalization of hard coal mines, national coke production, as well as through vertical integration with the iron mines in the Republic of Srpska, thus creating an adequate, more favourable raw material base.

In order to meet the electricity demand, Serbia firstly has to "replace" around 1,100 $\mathrm{mW}$ in obsolete power plants that are under the scope of the EU Directive on Large Combustion Plants and are at the end of their lifecycle with new production capacities. In case Serbia took the advantage of all potential at its disposal, it could meet its national 
electricity demand, which would be at the level of the demand in the developed countries, but under the condition that it raises its level of energy efficiency up to the level of those countries. This demonstrates great development and investment opportunities that would be beneficial for the machine, electro-mechanical and construction industries.

The manufacturing of weaponry and military equipment has been first developed in Serbia and proved to be the most resistant high-tech industry because it survived in spite of all challenges of the modern era. The largest potential for generating development in the field of industry and high technologies is precisely this branch of economy in Serbia, as well as practically self-originated IT industry. The existence of huge lithium reserves (Jadarit) in our territory provides great opportunities to enter the rapidly growing production of lithium batteries that serve as energy storage for cars and solar energy.

Given the parameters such as the area of arable land or the availability of water, Serbia is an insufficiently populated country. The population is one of the main economic resources because it provides labour and increases the number of entrepreneurs. For this reason, one of the main generators of development would be to increase the population of Serbia and its level of education. Given that trends in this area are extremely negative, and that control measures are neither economic nor related to logistics, they will not be considered in more detail.

The infrastructural projects that have been contracted so far will lead to the completion of the road corridor 10, a bypass around Belgrade and a section of Corridor 11. The construction of the Budapest-Belgrade fast track railway and the modernization of the Belgrade-Bar and Niš-Dimitrovgrad railways are relatively certain.

In regard to the energy supply, it can be said that the increase in the gas storage capacity and the construction of the gas interconnection Niš-Dimitrovgrad-Sofia will probably be implemented in due time. The similar thing goes for the OHL network through Serbia. Serbia is currently building a $350 \mathrm{~mW}$ Kostolac thermal power plant, which, along with renewable energy projects, could guarantee the replacement of $1,100 \mathrm{~mW}$ of outdated production capacities with new national capacities.

Serbia has a gas pipeline that connects it to Ukraine and Russia through Hungary. An interruption to the gas supply by this pipeline in winter periods, at present, would be a serious threat to the Serbian energy system since the volumes of electricity produced would not be sufficient to meet the energy needs in case of a disrupted gas supply, and the production of national gas is far below the level of demand. To a certain extent, such situation might be overcome merely by providing large gas reserves, or even dramatically improved if some of the internationally important gas pipelines such as the planned "Turkish Stream" or the frozen "South Stream" would go through Serbia.

Today, almost all volumes of imported oil are transported to Serbia by the pipeline from the Croatian port of Omišalj. The interruption in this route of supply would restrict Serbia to national oil production and potential imports by barges on the river Danube. The situation could be overcome over a limited period of time by large reserves of oil and petroleum products. For similar reasons as with gas, the support should be given to the construction of the Pan-European Oil Pipeline - PEOP (capacity of about 50 million tons a year) and Pitesti-Pančevo oil pipeline (capacity of 10-15 million tons per year), which would satisfy a significant part of the European needs and overcome problems and congestion in transport through Bosphorus and Dardanelles. The projects are currently frozen or in the early stages of consideration. The routes of these two oil pipelines virtually overlap in the section through Romania, Serbia and parts of B\&H and Croatia. 


\section{Conclusion}

The national logistics of the Republic of Serbia could be basically viewed in peacetime and emergency situations caused either by natural disasters, shorter armed conflict, war, blockade, etc.

The peacetime would have been characterized by general growth as the result of a good position of the country and economic growth. The increase in transport of goods and passengers would likely reach the rates higher than the economic growth rate (in $20155.9 \%$ growth in road transportation and $1.1 \%$ in railway transportation vs $0.8 \%$ of GDP growth) as the result of favourable geographical position of the country and growth of cross-border transportation. Road transportation will be dominant despite the strategic determination of Serbia to increase the volume of rail and river transport. Bearing in mind the existing infrastructure and the one which is currently under construction, it can be concluded that there is a surplus of capacity for the next few years almost in all transport segments. Telecommunication capacities also meet the current needs of the economy. Energy supply should also be stable despite some minor problems caused by technical disturbances or the consumption, which is higher than expected, especially in winter. In short, if the infrastructure were to follow the development of the economy, the national logistics would not be the bottleneck of the Serbian economy.

If it manages to bear the burden of a prolonged war and blockade, the national logistics of Serbia will also be able to meet the challenges implied by shorter conflicts and natural disasters. The problem of shorter conflicts is that they can be much more intense such as the 1999 bombing. In order to be able to provide support in high - intensity conflicts or major disasters, it has to rely on reserves and stocks of required materials and equipment because there will be no time to wait for them to be manufactured or imported. The question of protection of reserves is a specific and highly important matter.

It is interesting to consider which possibilities and logistics the Serbian economy may deploy in order to meet the needs of its population and security forces in the event of a breakdown in global relations or in the case of a long-term crisis as it was the case during the sanctions and wars in the 1990s. On the basis of what has been previously stated, all the needs could be classified into three groups according to the probability of being met. This is shown in Table 2.

Table 2 - Probability of meeting the needs based on current state of national logistics in Serbia

\begin{tabular}{|c|c|c|}
\hline $\begin{array}{l}\text { Needs mostly met with national } \\
\text { potential }\end{array}$ & $\begin{array}{l}\text { Needs partly met with } \\
\text { national potential }\end{array}$ & $\begin{array}{l}\text { Needs that cannot be met } \\
\text { with national potential }\end{array}$ \\
\hline $\begin{array}{l}\text { Food } \\
\text { Drinking water } \\
\text { Electricity } \\
\text { Construction of smaller structures, } \\
\text { road construction and repair } \\
\text { Staffing of security organizations and } \\
\text { providing services to population } \\
\text { IT needs } \\
\text { Needs for medical care of people } \\
\text { Needs for animal care } \\
\text { Needs for housing } \\
\text { Meteorological services } \\
\text { Needs for all modes of transport } \\
\text { Telecommunications needs }\end{array}$ & $\begin{array}{l}\text { Light infantry weapons, } \\
\text { artillery, military equipment } \\
\text { repair... } \\
\text { Ammunition } \\
\text { Manufacture of vehicles } \\
\text { Manufacture of rubber, } \\
\text { batteries and chemicals } \\
\text { Petroleum products } \\
\text { Natural gas } \\
\text { Heat energy } \\
\text { Needs for clothing and } \\
\text { footwear }\end{array}$ & $\begin{array}{l}\text { High-tech military and secu- } \\
\text { rity equipment such as } \\
\text { planes, tanks, helicopters, } \\
\text { etc., as well as spare parts } \\
\text { Communication and com- } \\
\text { puter equipment and parts }\end{array}$ \\
\hline
\end{tabular}


The first group includes the needs that can be met on the basis of national potential if stocks of certain materials would be supplied. Thus, for medical care, it is necessary to have supplies of medications, and for agriculture the supply of diesel and natural gas for the production of fertilizers. It is also necessary to have stocks of spare parts for machines, equipment and means of transport. A good portion of these supplies can be provided from own production.

The second group includes materials and equipment that can be produced in the country, but raw materials-resources are lacking. In this case, we would have to rely on supplies, as well, but much bigger ones. The third group consists of materials that cannot be produced in the country since technologies, production capacities and the critical level of knowledge and skills are not available.

Although Serbia can partially meet its own needs for oil and gas (about 25\%), these two materials remain critical because the lack of them affects the capacities of performing agricultural work, the production of artificial fertilizers, all forms of transport (and thus all branches of the economy and the movement of passengers and security forces), but also the heating and thereby survival of the population. It should be kept in mind that the lack of heating can cause the population to turn to the electricity consumption for heating, which would endanger the existing power system. Apart from oil and gas, the supplies of some types of ammunition, missiles and spare parts are also critical because without them the potential of existing weapons, vehicles and all kinds of equipment cannot be used.

From the security point of view, it would certainly be desirable if the government would do more to build national capacities for oil production and refining (especially oil shale), the production and transmission of electricity, as well as to create larger stocks of oil, oil products, gas, medications, seeds, food and other critical materials and equipment. In the long term, investments in the production of copper, Jadarit (lithium), phosphates, coal and iron mining in the region are also interesting. Investments in the IT industry, the production of computer and communication equipment, as well as the capacities for producing critical types of ammunition and missiles would have a positive effect on increasing the country's independence in crises. From the communicationinfrastructural point of view, oil pipelines, gas pipelines, communication by the Danube, Corridors 10 and 11 represent the national necessity.

The general conclusion is that elements of the national logistics system, except in some cases such as oil and gas, are not the limitation to ensuring normal operation. However, the system also comprises the regulatory framework and established connections between system components. Therefore, in addition to continuous work on the creation and finish of system elements, equally and perhaps even more important it is to work on the regulatory framework and establishment of good connections between the elements of the system.

\section{References}

[1] Report on economic development of Serbia in 2015, Ministry of Economy.

[2] National Bank of Serbia: Report on banking sector in Serbia for Q1 2015.

[3] Chamber of Commerce of Serbia (http://www.pks.rs/).

[4] Indikatori Svetske banke: obradivo zemljište po stanovniku, Makroekonomija, 13.06.2013. (http://www.makroekonomija.org/poljoprivreda/indikatori-svetske-banke-obradivo-zemljiste-po-stanovniku/) 
[5] Miroslav Zdravković, Raspoloživost pijaće vode u svetu, rang zemalja, Makroekonomija, 03.09.2013. (http://www.makroekonomija.org/0-miroslav-zdravkovic/raspolozivost-pijacom-vodomu-svetu-rang-zemalja/)

[6] Zabluda da je Srbija bogata vodom, Tanjug, 28.06.2014.

(http://www.srbijadanas.com/clanak/zabluda-je-da-je-srbija-bogata-vodom-27-06-2014)

[7] Nebojša Veljković, Milorad Jovičić, Environmental Report for the Republic of Serbia, Agency for Envrionmental Protection, 2010.

(http://www.sepa.gov.rs/download/konf2010/4_Kvalitet___kvantitet_vodnih_resursa.pdf)

[8] http://www.b92.net/biz/vesti/srbija.php?yyyy=2007\&mm=03\&dd=22\&nav_id=237707

[9] Website of the Government of the Republic of Serbia

(http://www.arhiva.srbija.gov.rs/cms/view.php?id=1021)

[10] http://www.b92.net/biz/vesti/srbija.php?yyyy=2007\&mm=03\&dd=22\&nav_id=237707

[11] Website of the Government of the Republic of Serbia

(http://www.srbija.gov.rs/pages/article.php?id=53)

[12] "Priprema nemetala u Srbiji". Ljubiša Andrić, ITNMS, 2009., Beograd (rezultati projekata TR33007 i TR34006 finasiranih od strane Ministarstva prosvete i nauke, Republike Srbije)

[13] Serbian Armed Forces (https://en.wikipedia.org/wiki/Serbian_Armed_Forces).

[14] Serbian defence industry (https://sr.wikipedia.org/sr/Namenska industrija).

[15] Website Jugoimport SDPR (http://www.yugoimport.com/lat/proizvodi)

[16] Group of wepons and military equipment manufacturers, Chamber of Commerce of the Republic of Serbia and Ministry of Defence, PARTNER 2013.

(http://www.pks.rs/SADRZAJ/Files/CMIP/Partner2103.pdf)

[17] http://www.novosti.rs/vesti/naslovna/ekonomija/aktuelno.239.html:453190-Fabrike-obuceu-Srbiji-se-masovno-zatvaraju

[18] Textile industry (https://sh.wikipedia.org/wiki/Tekstilna_industrija)

[19] http://www.politika.rs/scc/clanak/362933/Armija-od-7-000- Veb sajt Republičke direkcije za robne rezerve (http://www.rdrr.gov.rs/)

[20] http://www.politika.rs/scc/clanak/362933/Armija-od-7-000-honorarnih-lekara

[21] Decree on planned healthcare system network (Official Gazzette 92/2015)

[22] The results of population census in Serbia for 2011.

(https://sh.wikipedia.org/wiki/Popis_stanovni\%C5\%A1tva_u_Srbiji_2011)

[23]

http://www.danas.rs/danasrs/ekonomija/prihod_it_sektora_200_miliona_evra.4.html?news_id=286548

[24] Strategy for the development of rail, road, water, air and intermodal transport in the Republic of Serbia from 2008 to 2015 ("Official Gazette" No. 4/28).

[25] Website of The Yugoslav River Shipping (http://www.jrb.rs/index.php/sr/o-nama/companies)

[26] Air Srbija (https://en.wikipedia.org/wiki/Air_Serbia)

[27] RATEL - Overview of the telecommunications and postal services market in R. Serbia in 2015. 